\title{
Diakoni som teologisk fagområde, videnskab og nyt universitetsfag i Danmark
}

\author{
Lektor, ph.d. \\ Jakob Egeris Thorsen, Aarhus Universitet
}

\begin{abstract}
Since 2014, the Department of Theology at Aarhus University has offered a 2-year, interdisciplinary MA-program in Diaconia (Christian Social Practice). Thereby, diaconia has officially become an academic subject in a Danish university. The author uses this occasion to provide a general introduction to diaconia and its role in church and theology, to the science of diaconia, and to the character of the new MA-program. The article centers on the apparent paradox that while diaconia is becoming an increasingly important theological concept, especially in ecclesiology, the diaconal field of practice is characterized by interdisciplinarity and secularization. The author argues that the science of diaconia should reflect that situation and make it the starting point for a continuing constructive analysis of the role and identity of diaconia in an increasingly pluralist context.
\end{abstract}

Key words: diaconia - diakonia - diaconal science - diaconia research - ecclesiology

\section{Ny kandidatuddannelse i diakoni}

I 2014 oprettede Aarhus Universitet en tværfaglig kandidatuddannelse i diakoni, der blev forankret i Afdeling for Teologi på Institut for Kultur og Samfund. I 2017 blev der ligeledes oprettet et 3-årigt midlertidigt lektorat i diakoni og det er derfor nærliggende at skildre diakoniens plads i teologien, at beskrive den akademiske diakonividenskab i dag og at skildre den nye uddannelse i lyset heraf. Diakonien har som fag indtil nu haft hjemme på bl.a. Diakonhøjskolen i Aarhus og på Diakonissestiftelsen på Frederiksberg, men også universitetsteologer, som bl.a. Johannes Nissen, Hans Raun Iversen og Eberhard Harbsmeier har i større eller mindre omfang beskæftiget sig med den. ${ }^{1}$ Ligeledes har diakoniens opblomstring i det 19. og 20.

1. Johannes Nissen, Diakoni og Menneskesyn (Aarhus: Aros Forlag 2015 [2004]); Johannes Nissen, Håb på trods - Diakonale verdier i social- og sundhedsarbejde (Frederiksberg: Eksistensen 2019); Eberhard Harbsmeier \& Hans Raun Iversen, 
årh. været genstand for kirkehistorisk forskning. ${ }^{2}$ Ikke desto mindre giver etableringen af en kandidatuddannelse, der på Aarhus Universitet har fået en særlig profil, og relationen til et eksisterende fagmiljø anledning til at spørge, hvad der karakteriserer faget i en dansk sammenhæng. Før vi når dertil, vil artiklen først stille spørgsmålet, hvad der forstås ved diakoni, og hvad dens plads er i forhold til i teologi og kirke. Dette har nemlig betydning for, hvordan man forstår både diakonividenskaben og den akademiske uddannelse i diakoni. Dernæst præsenteres den nye uddannelse og endelig diskuteres det, hvilken profil diakonividenskaben har - og kan få - i en dansk universitetssammenhæng.

\section{Diakoni som teologisk begreb}

Kjell Nordstokke, der er én af diakoniforskningens grand old men i Skandinavien, skelner mellem hhv. en deduktiv og en induktiv forståelse af diakoni. ${ }^{3}$ I den deduktive er forståelse ses $\delta 1 \alpha \kappa o v i \alpha$ som et centralt nytestamentligt og teologisk begreb, der enten betyder en tjeneste i kirken og for verden, eller - mere snævert - omsorg og hjælp til syge, fattige og socialt udsatte. I den induktive forståelse ses diakonal praksis som et empirisk fænomen i verden (historisk og aktuelt), der kan og skal studeres fra en hel række forskellige videnskabelige perspektiver og med en række forskellige metoder. På sin vis er der i denne opdeling en klar parallel til teologien, der jo også både kan forstås snævert, som systematisk teologi (på engelsk "theology" eller "divinity") og bredt som studiet af kristendom i fortid og nutid, der jo både kan tilgås historisk, filosofisk, sociologisk, eksegetisk osv. Pointen hos Nordstokke er naturligvis, at det ikke er et spørgsmål om at vælge den ene frem for den anden forståelse af diakoni, men at de begge har en berettigelse og at studiet af diakoni er bedst, når det

Praktisk Teologi (Frederiksberg: Anis 1995), 161-195; Hans Raun Iversen, Ny Praktisk Teologi: Kristendommen, den enkelte og kirken (København: Eksistensen 2018), 307-351.

2. Se $\mathrm{fx}$ Liselotte Malmgart, Udviklingslinier i nyere dansk diakoni: social indsats og diakonal selvforståelse $i$ to kirkelige organisationer i det 20. århundrede: Samvirkende Menighedsplejer 1902-2002, Sankt Lukas Stiftelsen 1900-2000 (Ph.d.-afhandling, Det Teologiske Fakultet, Københavns Universitet 2002); Bodil E. Lodberg, Hus og hjem: en overset økonomi i protestantismen og det danske velferdssamfund (Ph.d.-afhandling Aarhus: Aarhus Universitet 2017).

3. Kjell Nordstokke, "The Study of Diaconia as an Academic Disciplin", i reds. Stephanie Dietrich \& Knud Jørgensen m.fl., Diakonia as Christian Social PracticeAn Introduction (Oxford: Regnum Books 2014), 48. 
to forståelser står i en gensidigt berigende og udfordrende spænding (Nordstokke 2014, 48).

\section{Diakoni central som ekklesiologisk bestemmelse}

Ser vi først på det deduktive teologiske diakonibegreb kan det, som antydet ovenfor, dække over to halvvejs overlappende betydninger: Den ene er diakoni som kirkelig funderet omsorgstjeneste for den syge og socialt udsatte. Det er den brug af ordet der er vokset frem i en nordvesteuropæisk, protestantisk tradition siden det 19. årh. og som i Danmark er den mest fremherskende forståelse. Den anden er diakoni som myndig kirkelig sendelse og tjeneste. Den forståelse har delvist overlevet i de ortodokse og katolske kirker, hvor diakonen har en særlig liturgisk funktion og kirkelige opgaver, selvom diakonembedet særlig på romersk-katolsk side i århundreder har været reduceret til en mellemtrin før den fulde præstevielse, og det først var efter II. Vatikankoncil, at et permanent diakonembede blev genoprettet. I vestlig teologi er det eksegeten John Collins, der fra 1970'erne og frem igen har sat fokus på diakoni som myndig kirkelig tjeneste. Det gjorde han ved i flere studier af betydningerne af diakoni i Det nye Testamente at påvise, at ordet på intet tidspunkt knyttes til omsorgen for de syge, fattige, fangerne eller andre særligt udsatte grupper (i menighed eller lokalsamfund), som skildres i NT, eller som vi i dag ser som modtagere eller brugere af diakonale indsatser. ${ }^{4}$ Den moderne protestantiske identifikation af diakoni med denne tjeneste har således ikke et nystestamenteligt eller oldkirkeligt forlæg. Det betyder naturligvis ikke, at den moderne brug af ordet ikke kan være yderst meningsfuld og relevant, da omsorg for svage og udsatte altid har været en del af kirkens virkeområde, blot at diakoni traditionelt betyder en myndig tjeneste i kirken.

Både den traditionelle og den nyere diakoniforståelse klinger med i den centrale betydning, som diakonien igen har fået i megen nyere protestantisk og katolsk ekklesiologi, der fra 1960'erne og frem blev udviklet under indflydelse af missio Dei-teologien og 2. Vatikankoncil. Her ses diakonien som et af kirkens tre udtryk eller som én af de tre måder, hvorpå kirken deltager i Guds missio. I denne forståelse er kirken et fælleskab (koinonia), som kommer til udtryk i martyria (forkyndelse, undervisning og profetisk vidnesbyrd), leiturgia (sakra-

4. John N. Collins, Deacons and the Church. Making connections between old and new (Herefordshire: Gracewing 2002), 13. 
mentsforvaltning, bønsliv og gudstjeneste) og diakonia (tjeneste ad intra og ad extra). På protestantisk side kan man fx nævne Darell L. Guder, og i en dansk sammenhæng arbejder både Hans Raun Iversen og Jeppe Bach Nikolajsen med en sådan ekklesiologisk tredeling. ${ }^{5}$ På katolsk side kan man nævne Yves Congar, Karl Rahner, Walter Kasper, Karl Lehmann og Gerhard Müller. ${ }^{6}$ Selvom beskrivelsen af kirken med disse tre udtryk er blevet problematiseret som værende i nogen grad vilkårlig og i værste fald begrænsende for en nuanceret kirkeforståelse, har den altså vundet vid udbredelse. ${ }^{7}$ Den er som sådan heller ikke ny, men kan genfindes helt tilbage hos Eusebius af Cæserea og blev senere videreudviklet hos Thomas Aquinas. ${ }^{8}$ Her modsvarer de tre udtryk martyria, leiturgia og diakonia Kristi trefoldige embede som profet, ypperstepræst og konge. Kirkens vidnesbyrd er ikke andet end Kristi eget vidnesbyrd, dens præstetjeneste (både den almene og den særlige) er delagtighed i Kristi præstedømme, og dens myndige tjeneste delagtighed i Kristi kongedømme, der efter omvendelsen af værdierne netop er en tjeneste. ${ }^{9}$ I nogle kirkesamfund vil disse udtryk embedsmæssigt være forankret i biskop, præst og diakon, selvom man typisk også vil sige, at det påhviler alle døbte at deltage i de tre udtryk i kraft af det almindelige (eller universelle) præstedømme (Müller 2016, 608). Denne forankring af diakonien i ekklesiologien har både på protestantisk og katolsk side fundet vej til kirkelige dokumenter. I det lutherske verdensforbunds dokument "Diakonia in Context" fra 2009 beskrives diakoni som en del af kir-

5. Darrell L. Guder, The Continuing Conversion of the Church (Grand Rapids: Eerdmans 1998), 53; Jeppe Bach Nikolajsen, Kirkens rolle i et pluralistisk samfund (Fredericia: Kolon 2017), 110 ff; Iversen (2018).

6. Yves Congar, "Die Wesenseigenschaften der Kirche", i reds. J. Fiener \& M. Löhrer, Mysterium Salutis: Grundriss heilsgeschichtlicher Dogmatik. Band IVII: Das Heilsgeschehen in der Gemeinde (Einsiedeln/Zürich/Köln: Benziger 1972), 375-599; Karl Rahner, "Theologische und pastoraltheologische Vorüberlegung", i reds F. Xaver \& K. Rahner m.fl., Handbuch der Pastoraltheologie. Praktische Theologie der Kirche in ihrer Gegenwart. Band 1 (Freiburg i.Br.: Herder 1964), 216-219; Walter Kasper \& Karl Lehmann, Die Heilssendung der Kirche in der Gegenwart. Pastorale. Handreichung für den pastoralen Dienst. Einleitungsfaszikel (Mainz: Matthias-Grünewald-Verlag 1970), 69-89; Gerhard Kardinal Müller, Katholische Dogmatik. Für Studium und Praxis der Theologie (Freiburg i.Br.: Herder 2016 [1995]), 608-609).

7. Fx Herbert Haslinger, Diakonie. Grundlagen für die soziale Arbeit der Kirche (Paderborn: Verlag Ferdinand Schöningh 2009), 169-171.

8. Gerald W. McCulloh, Christ's Person and Life-Work in the Theology of Albrecht Ritschl: With Special Attention to Munus Triplex (Boston, MA: University Press of America 1990), 151.

9. Jakob Egeris Thorsen,"The Church as a Dynamic Field of Priestly, Prophetic and Diaconal Tension. A Proposal for a Practical Ecclesiology Based on the Latin American Example", Ecclesiology 15 (2019), 171-187. 
kens esse og i en model sammesteds som ét af det kirkelige fællesskabs tre udtryksformer: ${ }^{10}$

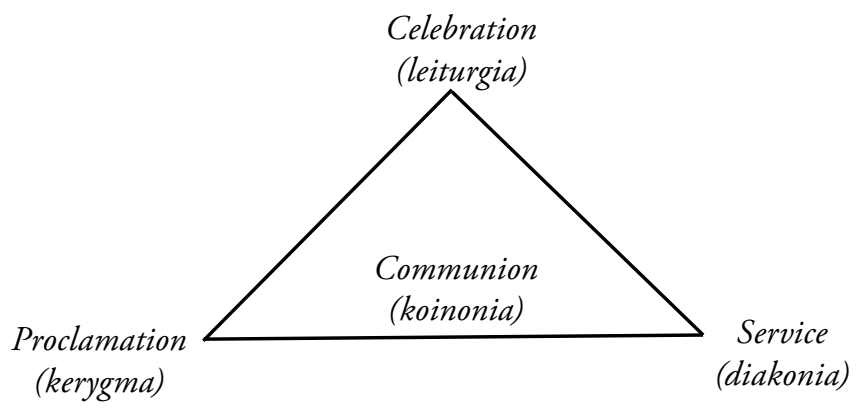

The dimensions of being Church

Modellen forklares således:

$[T]$ hat these three dimensions of celebration, proclamation and service are inter-related in a way that each one is rooted in the other two, and in fact would not exist without them. Diakonia cannot be separated from what the Church proclaims and celebrates. There is no hierarchy between them, and all are expressions of communion (LWF 2009, 29).

Også i officielle katolske dokumenter genfinder man samme tre-strengede forståelse af kirken, fx i Pave Benedikt XVIs diakoni-encyklika Deus Caritas Est (DCE) fra 2005, hvori det hedder:

The Church's deepest nature is expressed in her three-fold responsibility: of proclaiming the word of God (kerygma-martyria), celebrating the sacraments (leitourgia), and exercising the ministry of charity (diakonia). These duties presuppose each other and are inseparable. For the Church, charity is not a kind of welfare activity which could equally well be left to others, but is a part of her nature, an indispensable expression of her very being. ${ }^{11}$

Kort før sin tilbagetræden i 2013 blev encyklikaen fulgt kirkeretsligt op af et såkaldt Motu proprio med titlen Intima Ecclesiae Natura

10. Lutheran World Federation, Diakonia in Context: Transformation, Reconciliation, Empowerment (Geneve 2009), 27-29. https://www.lutheranworld.org/sites/ default/files/DMD-Diakonia-EN-low.pdf (besøgt 20.01.19).

11. Benedict XVI, Deus Caritas Est. Encyclical Letter (2005), \$25. http://w2.vatican. va/content/benedict-xvi/en/encyclicals/documents/hf_ben-xvi_enc_20051225_ deus-caritas-est.html (besøgt 20.01.19). 
(“On the Service of Charity"), hvor Pave Benedikt XVI i.f.t. kanonisk lov henordner alle kirkens diakonale aktiviteter under forskellige grader af biskoppeligt tilsyn for dermed at understrege diakoniens kirkelighed. ${ }^{12}$

Hvad der er interessant i sammenligningen af LWF-dokumentet og encyklikaen DCE er, i hvor høj grad diakonien inden for begge konfessioner har fået en central plads i ekklesiologien. Det er også interessant at bemærke, at førstnævnte i højere grad har en bred tjenesteforståelse af diakonien, dog med et hovedfokus på ad extra tjeneste for verden (profetisk diakoni, retfærdighed, udvikling), mens DCE i højere grad identificerer diakonien med den sociale omsorgstjeneste (caritas-tjenesten), og dermed i højere grad lægger sig op af en moderne protestantisk brug af diakonibegrebet, end den katolske kirkes egen diakoni-embedsforståelse, hvor diakonien både beskrives som en liturgisk, en forkyndelses- og en karitativ tjeneste. ${ }^{13}$

Begge konfessioners identifikation af diakonien som en del af kirkens esse i nyere ekklesiologi, rejser naturligvis spørgsmålet om, hvorvidt og hvordan diakoni også er eller børe være ekklesial, dvs. på en eller anden måde relateret til eller udgående fra kirken. Måske er her tale om en paradoksal udvikling, hvor kirkerne på deres side i stadig højere grad forstår sig selv som diakonale, mens megen diakonal praksis umiddelbart kan se ud til at rykke længere væk fra deres kirkelige udgangspunkt, både hvad angår sprog, selvforståelse og finansiering. Det er et spørgsmål, vi vender tilbage til sidst i artiklen.

\section{Diakoni som kirkelig-social omsorgstjeneste}

Ser vi på den anden, mere udbredte, karitative diakoniforståelse, betegner den kirkeligt og kristeligt socialt arbejde samt den teologiske begrundelse for samme. Dette har - naturligt nok - været et anliggende siden diakonien genopstod i sin moderne form fra midten af det 19. århundrede. Hvor Collins' brede forståelse af diakoni som myndig kirkelig tjeneste primært forankres i det ekklesiologiske hjørne af dogmatikken, bevæger vi i begrundelserne for den karitative diakoniforståelse i højere grad over i den teologiske antropologi og

12. Benedict XVI, Intima Ecclesiae Natura - On the Service of Charity. Apostolic Letter issued 'Motu Proprio' (2012). http://w2.vatican.va/content/benedict-xvi/en/ motu_proprio/documents/hf_ben-xvi_motu-proprio_20121111_caritas.html (besøgt 20.01.19).

13. Se fx Catechism of the Catholic Church - CCC (1997), \$\$569-1570. http://www. vatican.va/archive/ENG0015/_P1.HTM (besøgt 20.01.2019). 
i etikken. Begrundelsen for den karitative diakoni omhandler både grundlaget for og motivationen til det diakonale arbejde og fra midten af det 20 årh. også i stigende grad en overvejelse af, hvad der gør det diakonale arbejde diakonalt, dvs. om og hvordan den adskiller sig fra almenmenneskelig og statslig organiseret omsorg (Nissen 2015, 42).

Ser vi på begrundelserne for diakonien kan man opdele dem efter, om de er alment-humant eller religiøst begrundet. Er sidstnævnte tilfældet kan man endvidere se på i hvilket af de led i trosbekendelsen, der tages udgangspunkt; med andre ord om diakonien primært begrundes skabelsesteologisk, kristologisk eller eskatologisk, typisk ud fra Gudsrige-tanken. Jeg vil i denne gennemgang af den diakonale teologi lægge hovedvægten på udvalgt tysksproget litteratur, da den meget righoldige tradition her grundigt behandler de fleste af de tilgange og temaer, der findes inden for feltet. Det ligger desværre uden for rammerne af denne artikel at give en fyldestgørende gennemgang af den omfangsrige diakonalteologiske litteratur, der naturligvis forefindes på skandinavisk, engelsk, fransk og spansk. Her skal det bemærkes, hvordan diakoniens teologi endnu er regional og konfessionel. I forbindelsen med udarbejdelsen af denne artikel fokuserede jeg på tre nyere tyske værker nemlig Johannes Eurich og Heinz Schmidts antologi "Diakonik: Grundlagen - Konzeptionen - Diskurse", Herbert Haslingers monografi "Diakonie" (2009) og Christoph Sigrist \& Heinz Rüeggers antologi "Helfendes Handeln im Spannungsfeld theologischer Begründungsansätze" (2014). ${ }^{14}$ Det er iøjnefaldende, hvordan alle tre værker næsten eksklusivt refererer til tysksproget litteratur, og hvordan værkerne af de evangeliske teologer stort set ikke refererer til katolsk diakonal teologi og omvendt. Eurich, Schmidt, Sigrist og Rüegger optræder således ikke i den katolske Haslingers litteraturliste og vice versa. På det teoretiske plan må diakoniens teologi betegnes som kun i meget ringe grad økumenisk.

Før vi ser nærmere på de egentlige teologiske diakonibegrundelser er det værd at nævne de alment-menneskelige begrundelser for diakonien, som spiller en central rolle i dansk diakoni, hvor K.E. Løgstrup, men også E. Levinas' tænkning har været vigtig. Ifølge Løgstrup udtrykker den gyldne regel "Alt, hvad I vil, at mennesker skal gøre mod jer, det skal I også gøre mod dem” (Matt. 7,12) en radikal, før-kristen og universel etik, der retter et krav til mennesket om at sætte sig i næstens sted og handle derefter. Det opfattes netop som et bud, da det

14. Red. Johannes Eurich \& Heinz Schmidt, Diakonik. Grundlagen - Konzeptionen - Diskurse (Göttingen: Vandenhoeck \& Ruprecht 2016); red. Heinz Rüegger \& Christoph Sigrist, Helfendes Handeln im Spannungsfeld theologischer Begründungsansätze (Zürich: Theologischer Verlag Zürich 2014); Haslinger 2009. 
rettes til mennesket på trods af dets indgroede hældning mod at ville overhøre det og handle selvisk. Et eksempel er Levinas' tanke om, at mødet med den andens ansigt åbner et vindue til uendeligheden og påkalder sig min opmærksomhed, solidaritet og omsorg. ${ }^{15}$

\section{Skabelsesteologiske begrundelser}

De diakonibegrundelser, der i det 20. århundrede tager udgangspunkt i første trosartikel, er ifølge Ralf Hoburg et forsøg på en grundigere gennemtænkning og bredere forankring af diakonien end den efterfølgelsesteologi, der prægede det 19. århundredes diakonibevægelse. Ligeledes kan man på denne måde undgå en fremstilling, der har Paulus' diakonia-begreb som omdrejningspunkt. Formålet er at formulere en teologisk reflekteret begrundelse for "social handling", der forankres i antropologien og således bedre kan beskrive diakoniens sociale dimension. Ifølge Hoburg kan man endvidere identificere fire forskellige varianter af diakonal tænkning, der tager udgangspunkt i første trosartikel. ${ }^{16}$

I den første forstås diakoni som socialitet ud fra Guds væren. Her er Frank Crüsemanns eksegetiske undersøgelse af de jødiske sociallove i GT et godt eksempel. Ifølge ham er der en indre sammenhæng mellem gudsforståelse og retfærdighed, og GT udfolder i det hele taget sin sociale dimension med udgangspunkt i menneskets nød og klage. ${ }^{17}$ Guds gud-væren defineres ud fra hans barmhjertighed og retfærdighed, der forankres i gudsbegrebet. Crüsemann ender ligefrem med at konkludere, at

(...) das Durchsetzen solchen Rechts [der Armen und Elenden] wird damit zum Kriterium für das Gottsein Gottes selbst. Im Ringen der Armen und Elenden um ihr Leben und ihr Recht, geht es um nichts Geringeres als um das Gottsein Gottes (Crüsemann 1990, 86).

Den anden variant, der af Hoburg sammenfattes under overskriften "diakoni som bortgivelsen (Entäußerung) af Guds socialitet i barmhjertighed”, ligger i forlængelse af den første, men flytter fokus fra Guds væsen til meddelelsen af samme, Guds interesse og aktive om-

15. K.E. Løgstrup, "Etiske begreber og problemer", Etik och kristen tro, red. G. Wingren (Lund-København-Oslo 1971), 213; Emmanuel Levinas, Fanomenologi og Etik (København: Gyldendal 2002), 20; Nissen 2015: 43.

16. Ralf Hoburg, "Theologische Begründigungen der Diakonie", i Eurich \& Schmidt (2016), \$3.1.1.

17. Frank Crüsemann, "Das Alte Testament als Grundlage der Diakonie", Diakonie - biblische Grundlagen und Orientierungen. Ein Arbeitsbuch zur theologischen Verständigung über den diakonischen Auftrag, VDWI 2, red. Gerhard K. Schäfer \& Theodor Strohm (Heidelberg: Heidelberger Verlags-Anstalt 1990), 67. 
sorg (Zuwendung) for mennesket (Hoburg 2016, 3.1.1.2). Som eksempel på denne variant nævner Hoburg Hans-Jürgen Benedict, der med sit vægtlægning på Guds aktive omsorg afleder den menneskelige adfærds "pro-sociale struktur" fra Guds væsen frem for fra det rent menneskelige. ${ }^{18}$

Den tredje variant, "diakoni som menneskets evne til at handle solidarisk" eksemplificeres af Hoburg ved Gerd Theissens udlægning af lignelsen om den barmhjertige samaritaner, hvori han forsøger at bygge bro mellem eksegesen og humanvidenskaben. ${ }^{19}$ Theissen viser, hvordan der i anden halvdel af lignelsen ikke argumenteres teologisk, men alment-menneskeligt. At hjælpe bliver således forstået som et gensidigt socialt forhold frem for et guddommeligt lovbud. På samme måde som Crüsemann kommer han frem til en forståelse af social handling som en eksistentiel respons på den forefundne nød. Når socialiteten begrundes i Gud, betyder det ligeledes en opgradering af humanvidenskaberne som teologisk relevant erkendelsesveje (Hoburg 2016, 3.1.1.3).

Den fjerde variant, som Hoburg benævner "diakoni som aspekt ved skabelsesvirkeligheden” er et eksplicit skabelsesteologisk forsøg på at bestemme diakonien (ibid., 3.1.1.4). Her kan de reformerte teologer Christoph Sigrist og Heinz Rüegger fremføres som gode eksempler. For dem handler det om at give en teologisk begrundelse for menneskets medfødte, naturlige evne at være "pro-sociale" og solidariske. For at kunne give en sådan, må teologien gå i dialog med humanvidenskaberne og vise "Anknüpfungspunkte" mellem fænomenet "at hjælpe" og diakonal handling. For at indkredse det diakonale må teologien via eksegetisk og dogmatisk refleksion nå til en teologisk fortolkning af humanvidenskabelige og biologiske indsigter. ${ }^{20}$ Barmhjertighed og empati bliver bestemt til at være en del af den antropologiske grundbestemmelse af mennesket som et "pro-socialt" væsen, og dér sker der et sammenfald mellem det kristne og det menneskelige. Formålet er at vriste den "hjælpende handling" ud af det kristne favntag ("den kristologiske fælde") og mane enhver tanke om kristnes omsorgsmæssige overlegenhed i jorden. Sigrist og Rüeggers diako-

18. Hans-Jürgen Benedict, Barmherzigkeit und Diakonie. Von der rettenden Liebe zum gelingenden Leben, Diakonie 7 (Stuttgart: Kohlhammer 2008), 9-28; Hoburg 2016, \$3.1.1.2.

19. Gerd Theissen, "Die Bibel diakonisch lesen. Die Legitimitätskrise des Helfens und der barmherzige Samariter", Studienbuch Diakonie I. Biblische, historische und theologische Zugänge zur Diakonie, red. Volker Hermann \& Martin Horstmann (Neukirchen-Vluyn: Neukirchner Verlag 2006), 90; Hoburg 2016, \$3.1.1.3.

20. Heinz Rüegger \& Christoph Sigrist, Diakonie - Eine Einführung. Zur theologischen Begründung helfenden Handelns (Zürich: Theologischer Verlag Zürich 2011), 119-120. 
nibestemmelse er bl.a. af Johannes Eurich blevet kritiseret for slet ikke at tage højde for syndefaldet, dvs. det faktum, at det "naturlige" menneske netop ofte ikke udviser socialitet, solidaritet og empati, når det burde. ${ }^{21}$ Det faktum, at hjælpende pro-social handling naturligvis også forefindes i andre kulturer og religioner betyder ikke, at der ikke kan og må være et særligt kristent perspektiv på fænomenet, og at dette perspektiv kan være potentielt berigende i det interkulturelle og interreligiøse møde. Netop indsigten om menneskets syndighed, der også altid bringer den hjælpende i fare for at handle selvisk, kan være et kristent bidrag til en fælles refleksion over, hvordan medmenneskelig hjælp kan og bør forvaltes (Eurich 2014, 206).

\section{Kristologiske begrundelser}

Diakoni som efterfølgelse af Kristus stod i centrum som begrundelse for diakonien ved den moderne diakonis opblomstring fra det 19. århundrede, som var tæt forbundet med den store indremissionske mobilisering. Denne efterfølgelsesdiakoni blev i det 20. årh. kristologisk uddybet og begrundet, senere særligt under indflydelse af R. Bultmann og K. Barths teologier. Som et tidligt eksempel på en kristologisk centreret diakonal teologi kan man nævne Wilhelm Brandt, der forstår diakonien som en efterfølgelse af Kristi hjælpende tjeneste. Brandt begrunder diakonien i Kristi trefoldige tjeneste, og ser kirkens diakoni som en eksistentiel livsform, der er udledt af Kristi gerning (Hoburg 2016, \$3.1.2.1). En videreudvikling af Brandts jesulogiske efterfølgelsesdiakoni findes hos Horst Seibert og Reinhard Turre. ${ }^{22}$ Den, der nok imidlertid særligt bliver forbundet med en velunderbygget stærk kristocentrisk diakonal teologi, er Paul Philippi, som på baggrund af en eksegetisk argumentation viser, hvordan kristologien må forstås "diakono-centrisk" ${ }^{23}$ Den tjenende Messias bliver ophav til et efterfølgelses- og discipelfællesskab, der kvalitativt orienterer sig efter Kristusbegivenheden, og hvis diakonale tjeneste dermed bliver

$\overline{21 . ~ J o h a n n e s ~ E u r i c h, ~ " D i a k o n i e ~ a n g e s i c h t s ~ d e r ~ H e r a u s f o r d e r u n g ~ i n t e r r e l i g i o ̈ s e r ~ B e-~}$ gegnungen", Helfendes Handeln im Spannungsfeld theologischer Begründungsansät$z e$, red. Heinz Rüegger \& Christoph Sigrist (Zürich: Theologischer Verlag Zürich 2014), 202.

22. Wilhelm Brandt, "Der Dienst Jesu”, Das diakonische Amt der Kirche, red. Herbert Krimm (Stuttgart: Evangelisches Verlagswerk 1953); Horst Seibert, Diakonie. Hilfehandeln Jesu und Soziale Arbeit des Diakonischen Werkes. Eine Überprüfung der Gegenwärtigen Diakonie an ihrem theologischen und sozialen Anspruch (Güthersloh: Gütersloher Verlagshaus Mohn 1983); Reinhard Turre, Diakonik. Grundlegung und Gestaltung der Diakonie (Neukirchen-Vluyn: Neukirchener Verlagsgesellschaft 1991).

23. Paul Philippi, Christozentrische Diakonie. Ein theologischer Entwurf (Stuttgart: Evangelisches Verlagswerk 1975 [1963]), 4. 
realiseringen af en eskatologisk eksistens. Denne går imidlertid over korset, så efterfølgelsen i den diakonale tjeneste er også en efterfølgelse i lidelse og selvopofrelse (Philippi 1975, 104-107). Den kristocentriske diakoni bliver således også tæt forbundet med forestillingen om menigheden som diakonalt fællesskab (Hoburg 2016, 3.1.2.2).

En nyere begrundelse, der i langt højere grad formår at forbinde en kristocentrisk tilgang til diakonien med en bredere human- og socialvidenskabelig beskæftigelse med "hjælpende handlen" er Annika C. Albert, der med udgangspunkt i retfærdiggørelseslæren ser diakoni ud fra et gave og gensidighedsperspektiv, der kan knytte antropologi og kristologi sammen (ibid., 3.1.2.3). Dermed bliver det muligt både at forstå diakonien som et alment menneskeligt og et specifikt kristent fænomen. Der skabes med andre ord en forståelsesramme for hjælpende solidarisk handling, der er er åben over for de mange forskellige perspektiver, der forefindes i en moderne, sekulær kontekst, samtidig med at den er begrundet i kristologisk i forestillingen om retfærdiggørelsen, der rækkes mennesket som en gave. ${ }^{24}$

\section{Gudsrige-begrundelser}

Endelig er der begrundelser, der tager udgangspunkt i trosbekendelsens tredje led. Selvom pinsekirkerne er i eksponentiel global vækst og ofte har en stærk menighedsdiakoni som et centralt kendetegn, så er denne hjælpende omsorg yderst sjældent genstand for teologisk refleksion. Karismatisk-pentekostal teologi tager udgangspunkt i udgydelsen af Helligånden, men der findes altså kun få ansatser til at tænke teologisk om diakoni og social omsorg. ${ }^{25}$ Men der findes andre teologer, der har formuleret diakonibegrundelser med udgangspunkt i det tredje led. Her er det Gudsrigets eskatologiske frembrud, der typisk er i centrum. Jürgen Moltmanns værk "Diakonie im Horizont des Reiches Gottes. Schritte zum Diakonentum aller Gläubiger" er en klassiker. ${ }^{26}$ I den skildrer han diakonien inden for den nye messianske tid, som er brudt frem med Kristi komme, Gudsrigets horisont. Kristus har bragt frelsen igennem sine frelsende handlinger og et nyt

\footnotetext{
24. Anika Christina Albert, "Christologische Begründung diakonischen Handelns im Lichte der Rechtfertigungslehre”, Helfendes Handeln im Spannungsfeld theologischer Begründungsansätze, red. Heinz Rüegger \& Christoph Sigrist (Zürich: Theologischer Verlag Zürich 2014), 56.

25. Se fx Peter Althouse, "Towards a Pentecostal Ecclesiology: Participation in the Missional Life of the Triune God", Journal of Pentecostal Theology 18 (2009), 230245; Amos Yong, The Spirit Poured out on all Flesh-Pentecostalism and the Possibility of Global Theology (Grand Rapids: Baker Academic 2005), 43-45, 65-68, 89-90, 163-164, 187-190.

26. Jürgen Moltmann, Diakonie im Horizont des Reiches Gottes. Schritte zum Diakonentum aller Gläubiger (Neukirchen-Vluyn: Neukirchener Verlag 1984).
} 
liv i Guds nærhed er brudt frem. Diakonien ses som en alsidig næstekærlig forsoningstjeneste og bør således gennemsyre kirken, hvormed Moltmann, ligesom Paul Philippi, knytter diakonien tæt til menigheden og er kritisk overfor den store organiserede anstalts-diakoni (Hoburg 2016, 3.1.4.2). Det mest spændende og banebrydende ved Moltmanns tænkning er imidlertid hans forståelse af næsten, som hos ham ikke er objektet for diakonal handling, men tværtimod ses som et subjekt i Guds Rige, en "Reichsgenosse”, én af Menneskesønnens søstre og brødre, hvormed han nedbryder den asymmetri, der ligger i forholdet mellem hjælperen og den, der bliver hjulpet. I Gudsriget er alle ligeværdigt modtagende (Moltmann 1984, 26-28). Inden for Gudsrigebegrundelserne må man slutteligt også nævne de befrielsesteologisk-inspirerede diakoniforståelser, hvor kristendommens profetiske og transformative potentiale står i centrum. På skandinavisk grund må man nævne Kjell Nordstokkes "Liberating Diakonia" som et eksempel herpå. ${ }^{27}$ Den befrielsesteologiske metode "see-judge-act" har endvidere, som vi skal se nedenfor, vundet bredt indpas i diakonividenskaben.

\section{Diakoni som praksisfelt}

Ser vi derimod på det induktive diakoni-begreb, så dækker det over fænomenet kirkelig eller kristent-inspireret hjælpende handling. Begrebet refererer typisk til den kristne sociale praksis, der opstod i Nordvesteuropa i 19 årh., som en del af den kirkelige mobilisering inden for social og sundhedsområdet. Diakonien har her sidenhen i høj grad selvstændiggjort sig som et separat praksisfelt i forhold til kirken og har kun delvist og nogle gange i lav grad overlap med det kirkelige felt (Nordstokke 2014, 48-49). De diakonale institutioner og organisationer fungerer (også) inden for en velfærds-, social- og sundhedssektor, der opererer efter egne regler, med eget vokabular, politiske målsætninger osv., hvor horisonten er eksklusiv-humanistisk. For rigtig mange i den diakonale sektor udgør denne induktive forståelse af diakoni som et forhånden værende praksisfelt naturligvis den primære forståelse af, hvad diakoni er, og den teologiske forståelse er - om end ikke altid helt ukendt - så dog i hvert fald fjern; ofte forstået som en form for arv, hvis relevans er omdiskuteret. I takt med at internationale og økumeniske kirkelige organisationer som Det Lutherske Verdensforbund (LWF) og Kirkernes Verdensråd

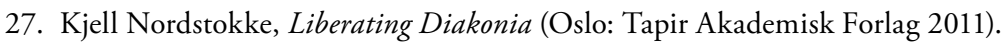


(WCC) anvender ordet diakoni om kristen social praksis, er begrebet (i dets nyere brug) ved at blive løsnet fra sit nordvesteuropæiske og protestantiske ophav, og selvom det endnu anvendes forholdsvist sparsomt i katolske, evangelikale og ikke-europæiske kredse, vinder det dog gradvist udbredelse. Det faktum at diakonibegrebet vinder udbredelse globalt, samtidigt med at det, der kan forstås som det "oprindelige" diakonale praksisfelt, i Nordvesteuropa gradvist bliver selvstændiggjort, understreger endnu engang vigtigheden af det ovennævnte spørgsmål om diakoniens kirkelige forankring. Dette er direkte relevant for diakonividenskaben i forhold til spørgsmålet om, hvilken rolle teologien spiller heri.

\section{Diakonividenskab}

Diakonividenskab er typisk blevet defineret i tråd med en schleiermachersk forståelse af den praktiske teologi, nemlig som en "teori over den diakonale praksis" eller som en teologisk orienteret praksisvidenskab (Haslinger 2009, 22). Det betyder hverken, at man blot undersøger den givne praksis empirisk-deskriptivt, eller at den diakonale praksis blot er en udførsel af den diakonividenskabelige teoridannelse. Det er tværtimod en vekselvirkning, en cirkulær proces. Men hvad er diakonal praksis, dvs. diakonividenskabens genstand? Det er der, som man kan regne ud, ikke enighed om i det tyskdominerede "Scientific Community der Diakoniewissenschaft". Johannes Eurich, én af de dominerende stemmer i tysk diakonividenskab, identificerer sammen med Ellen Eidt særligt tre problemer i forbindelse med bestemmelsen af genstandsfeltet. Først spørger de, hvorvidt diakonal praksis i et eller andet omfang skal være kristeligt begrundet og orienteret, eller er enhver hjælpende praksis automatisk 'diakoni', dvs. medmenneskelig tjeneste, også selv om de involverede ikke selv er klar over det, har en kristelig horisont eller kirkelig forankring. Skal de involverede have en eksplicit viden om den kristeligt-diakonale fortolkningshorisont, eller rækker det, at den diakonividenskabelige iagttager ser en måske implicit forbindelse? ${ }^{28}$ For det andet spørger de, hvad der kan gælde som diakonal praksis. Skal den traditionelt forstået være hjælpende handling til næsten, eller kan man tage ved lære af John Collins' førnævnte studier, der jo bestemmer diakoni meget bredere som (kirkelig) tjeneste, der jo kunne omfatte fx po-

28. Eidt, Ellen \& Johannes, "Theoretische Grundfragen und aktuelle Entwicklungen der Diakoniewisenschaft", Eurich \& Schmidt 2016, 7.1.3. 
litisk lobbyarbejde? Et tredje helt centralt og stadig mere aktuelt spørgsmål er, hvordan man som professionel diakonal institution og organisation skal forholde sig til de forskellige systemtrationaliteter, man møder i samarbejdet med det offentlige. Særligt i lande som Tyskland, hvor langt størstedelen af det diakonale arbejde udføres på vegne af det offentlige og er reguleret af offentlig lovgivning, må og skal de kirkeligt forankrede diakonale aktører overveje, om og hvordan de etisk kan stå inde for de rammer og vilkår, der gives for deres arbejde. Tilpasser man sig ukritisk reformerne og effektiviseringerne i den moderne velfærds- eller socialstat, eller kan en delvis retræte være nødvendig (Eidt og Eurich 2016, 7.1.3)?

Med et genstandsfelt, som rækker så langt ud over det snævert kirkelige, er det indlysende, at diakonividenskaben også overlapper med andre fag og derfor potentielt er en tværfaglig videnskab på samme måde som teologien (bredt forstået) er det. Spørgsmålet er imidlertid, hvilken form for tværfaglighed, der er tale om, og hvad teologiens rolle er. Da det diakonale genstandsfelt traditionelt forstået også hører hjemme inden for sundheds- og socialområdet, der er adskilt fra det kirkelige, må diakonividenskaben nødvendigvis også forholde sig til "socialt arbejde", socialpædagogik, organisationssociologi, ledelsesteori, økonomi m.m. Stort set alle, der engagerer sig i diakonividenskab, vil samtidig argumentere for, at teologien uundgåeligt må være én af fagets videnskabelige partnere (Bezugswissenshaft). Spørgsmålet er imidlertid, om den også skal være den ledende videnskab (Leitwissenschaft), sådan som den var tidligere. Er teologien (særligt den praktiske teologi) med andre ord diakonividenskabens primære basisvidenskab eller er teologien blot er én blandt flere (ligeværdige) videnskaber som undersøger fænomenet diakoni (ibid., 7.1.4)? Før vi hører Eidt \& Eurichs bud på det, er det værd at se nærmere på forskellige former for tværfaglighed, hvilket Beate Hoffmann har gjort i forhold til diakonividenskaben. ${ }^{29}$ Hun skelner mellem multidisciplinaritet, interdisciplinaritet og transdisciplinaritet. Den multidisciplinære tilgang er den mindst integrerede og består $i$, at et fænomen i det diakonale genstandsfelt undersøges uafhængigt af forskellige videnskaber, der hver fremlægger deres egen konklusion. Hvad der eksempelvis for økonomen er et knaphedsproblem, er for socialfilosoffen et retfærdighedsproblem og for psykologen en framingproblem. En sådan tilgang er ikke i egentlig forstand tværfaglig, og der kan ikke siges at eksistere en selvstændig diakonividenskab uafhængigt af de involverede discipliner. I den interdisciplinære tilgang er der en kontinuerlig

29. Beate Hoffmann,"Formen der Interdisziplinarität in der Diakoniewissenshaft", i Eurich \& Schmidt, 2016, 7.2. 
dialog mellem de forskellige involverede videnskaber over tid, der sker en udveksling af viden og indsigter, og fælles problemstillinger formuleres. De forskellige perspektiver bevares, men man forsøger at formulere fælles konklusioner. Endelig kan det tværfaglige samarbejde udvikle faget til blive transdiciplinært, hvor grænserne mellem fagene bliver gradvist mere utydelige eller helt opløses (Hoffmann 2016, 7.2). De fleste er enige om, at den eksisterende diakonividenskab i høj grad er interdisciplinær, og spørgsmålet er, om Hoffmanns ideal om at blive transdisciplinær overhovedet er efterstræbelsesværdig. Det spørgsmål vender vi tilbage til længere fremme.

Eidt og Eurich mener, at det må være teologiens rolle at have en normorienterende funktion: den identificerer og vurderer de normative beslutninger, der træffes, og der enten implicit eller eksplicit arbejdes efter i praksisfeltet, og den udlægger og fortolker pro-aktivt bibelske og dogmatiske vidnesbyrd ind i en aktuel situation. Teologiens forhold til de andre videnskaber i diakonividenskaben er således ikke konstant, men afhænger tematisk af, hvilket område der behandles og vil nogle gange fylde mere, andre gange mindre (Eidt \& Eurich 2016, 7.1.4).

Ser vi på den fremherskende arbejdsmetode i diakonividenskaben fremhæver mange, som nævnt ovenfor, en befrielsesteologisk inspireret og modificeret see-judge-act-tilgang. Eidt og Eurich tilføjer imidlertid "orientering" som et punkt før "se" for at imødegå en traditionel kritik af metoden for ukritisk at overtage implicitte og udefrakommende forforståelser i beskrivelsen af virkeligheden. "Orientering" handler derfor om at lave en selvrefleksiv bestemmelse af eget ståsted: hvilken normativ orientering anses for at være givet hos mig selv, dem jeg undersøger og eventuelle projektpartnere? Hvilke rammebetingelser er givet? Hvad fokuseres der på, og hvad udelades? Hvilke grundantagelser og metodiske tilgange er til stede i de andre videnskabelige discipliner, der indgår i undersøgelsen? Alt dette er særlig vigtigt at få klarlagt $\mathrm{i}$ en tværfaglig kontekst (ibid.; Eidt \& Eurich, 7.1.5). Efter denne refleksive før-orientering følges metoden traditionelt:

1. "At se": Alle former for undersøgelse af forekommende diakonal praksis, historiske kilder etc. ved hjælp af beskrivelser og analyser.

2. "At bedømme": med hjælp af udefrakommende referencepunkter (fx teorier, normative standpunkter etc.), forsøger man forstå og bedømme det undersøgte.

3. "At handle": her samles de tværfaglige resultater i en ny mulig teoridannelse med henblik på at orientere den diakonal praksis (ibid., 7.1.5). 


\section{Diakoniuddannelsen i Aarhus}

Ser man på kandidatuddannelsen i diakoni på Aarhus Universitet (AU), så har den en tværfaglig karakter, da den er et samarbejde mellem tre forskellige institutter: Kultur og Samfund (teologi), Virksomhedsledelse og Statskundskab. Det afspejler sig i studiets opbygning, hvor hver af de tre partnere tager ansvar for fagene.

\begin{tabular}{|c|c|c|c|}
\hline 1. semester & $\begin{array}{c}\text { Indføring i dia- } \\
\text { koni (teologi) }\end{array}$ & $\begin{array}{c}\text { Bibelsk } \\
\text { eksegese } \\
\text { (teologi) }\end{array}$ & $\begin{array}{c}\text { Organisati- } \\
\text { on og ledelse } \\
\text { (statskundskab) }\end{array}$ \\
\hline 2. semester & $\begin{array}{c}\text { Diakoni og } \\
\text { dogmatik } \\
\text { (teologi) }\end{array}$ & $\begin{array}{c}\text { Entreprenør- } \\
\text { skab (virksom- } \\
\text { hedsledelse) }\end{array}$ & $\begin{array}{c}\text { Evaluering og } \\
\text { Kvalitetssikring } \\
\text { (statskundskab) }\end{array}$ \\
\hline 3. semester & $\begin{array}{c}\text { Diakonal etik } \\
\text { (teologi) }\end{array}$ & $\begin{array}{c}\text { Social innova- } \\
\text { tion (virksom- } \\
\text { hedsledelse) }\end{array}$ & $\begin{array}{c}\text { Projekt/valgfag } \\
\text { (teologi og } \\
\text { andre) }\end{array}$ \\
\hline & Speciale & & \\
\hline
\end{tabular}

Sammenligner man kandidatuddannelsen i Aarhus med tilsvarende i Tyskland og Norge, er der mange ligheder, men også nogle forskelle. For det første er der på AU et større fokus på innovation og entreprenørskab, hvor der i tyske programmer typisk vil lægges større vægt på "Diakonie-management", dvs. driftsledelse. I det norske kandidatprogram, der udbydes i fællesskab af MF Vitenskapelig Høyskole for Teologi, Religion og Samfunn og VID vitenskapelige høgskole i Oslo, er der et lidt mere pastoralt fokus med fx sjælesorg. Dette afspejler meget godt de forskellige vilkår for diakonalt arbejde i de forskellige lande, med en stor offentligt finansieret diakonal sektor i Tyskland og diakoner som en efterhånden normal del af personalet ved norske kirker. I Danmark afspejler AU's fokus, at diakonien er ved at gå nye veje med et stigende samarbejde med det offentlige og øvrige aktører i civilsamfundet. Et andet kendetegn ved kandidatuddannelsen i Aarhus er, at de traditionelle teologiske fag næsten er repræsenteret én til én (eksegese, praktisk teologi og kirkehistorie, dogmatik og etik). Det har nogle fordele og ulemper. Fordelen er, at det afspejler at diakoni er forankret i hele teologien og ikke blot er en specialisering inden for Praktisk Teologi. Ligeledes giver det kandidaterne en bred indføring i teologien, kendskab til bibel, 
troslære og kirkehistorie. Dermed får de udviklet et teologisk sprog, noget der efterspørges af aftagerne, de diakonale arbejdspladser, der ønsker såkaldte kulturbærende medarbejdere, der kan begrunde og italesætte diakonien også over for kirke- og kristendomsfremmede. Ulempen ved denne opbygning er, at den kan afspejle, at en kandidat i diakoni skal være en mini-teolog, og at de enkelte teologiske fag på uddannelsen menes at have en berettigelse i sig selv, uden at diakonien og fagenes evt. relevans for den står i centrum og er bestemmende for deres inkorporering. Hvis uddannelsen på et tidspunkt skal igennem en større revision af studieordningen, kunne det være en god anledning til at gentænke ovennævnte forhold og til at overveje, hvilke teologiske elementer, der skal indgå og hvordan. Endelig er det også et kendetegn ved diakoniuddannelsen i Aarhus, at den ikke er en overbygning til én bestemt bacheloruddannelse. Således er det de fleste steder, og det viser, at diakonividenskab - med Anette Nollers ord er en "interdisciplinær doppelt-kvalificerende sammensat disciplin" (Verbunddisziplin), hvor diakoni-studerende typisk har en anden BA-uddannelse, der kombineres med diakonien, fx diakoni og socialarbejde, diakoni og socialpædagogik, diakoni og sygepleje. ${ }^{30}$ De fleste af de kandidatstuderende har således en professionsbachelor baggrund og er fx socialpædagoger, sygeplejersker eller socialrådgivere med erhvervserfaring. Det er et sigte med uddannelsen at hjælpe de studerende til hver især at danne en faglig identitet, der kombinerer deres respektive fagligheder med diakonien.

\section{Et selvstændigt fag?}

Al denne tværfaglighed, både i diakonividenskaben, hos de studerende og underviserne, i kombination med det store fokus på praksis, gør at diakonividenskaben naturligt nok bliver anvendelsesorienteret. Det gør imidlertid også, at der kun svært kan danne sig en fælles transdisciplinær diakonal videnskabelighed, som $\mathrm{fx}$ for Beate Hoffmann er et efterstræbelsesværdigt ideal $(2016,7.2)$. Jeg mener, at der er en styrke i interdisciplinariteten, som man kunne risikere at sætte over styr, dersom man bevægede sig i en transdisciplinær retning. Jeg ser primært to farer ved en udgrænsning af diakonividenskaben som en helt selvstændig akademisk disciplin: for det første ville teologien (men også sociologien, socialpædagogikken osv.) gå glip af

30. Noller, Annette (2016). "Diakoniewissenschaft als interdisziplinäre doppelt qualifizierende Verbunddsiziplin”, i Eurich og Schmidt (2016), 7.4. 
diakoniens praktiske indspark og de mange teologiske, pædagogiske og etiske problemstillinger, som rejses i det diakonale felt. For teologien ville det være et stort tab. For det andet ville det også være et tab for diakonien: Det ville risikere at svække de høje videnskabelige standarder, som findes i de etablerede videnskaber (teologi, sociologi, management etc.). Der er - i mine øjne - inden for diakonividenskaben en risiko for at blive det, som Thomas Gammeltoft Hansen (professor MSO på Københavns Universitet) i et interview på forsiden af Weekendavisen den 16. feb. 2018 med lån fra P. Bourdieu kalder et "svagt felt". I en kritik af flygtningeforskningen, som sikkert også kunne udbredes til andre nye, tværfaglige akademiske fag, beskriver Gammeltoft-Hansen, hvordan feltet er præget af en høj grad af idealisme og sympati med genstanden for ens forskning. Samtidig gør tværfagligheden, at der ikke er én videnskabelig traditions standarder at leve op til. Det skaber en usund konsensus og en lavere videnskabelig standard med små lukkede publikationsmiljøer, overlappende interesser, $\mathrm{fx}$ i forhold til projektfinansiering. Mange har skiftende kasketter, cirkulerer mellem universitetet og organisationsverdenen og har derfor en naturlig tendens til ikke at ville save grene over eller at spille sig muligheder af hænde ved i deres forskning at gå imod den herskende konsensus. Sådan står det heldigvis ikke til i diakonividenskaben, men der er tendenser i den retning, hvor der kan herske en forurettet og sjældent udfordret grundtone af, at vi i Vesteuropa lever i uretfærdige, ulige og usolidariske samfund, der afvikler velfærdsstaten og lader hånt om samfundets svageste, og at løsningen derfor altid er mere velfærd og - naturligvis - mere diakoni. Det bedste værn mod "det svage felts" usunde konsensus er de gamle videnskabers tradition for uenighed og åbne udvekslinger. Derfor er udviklingen af en ny, helt selvstændig transdisciplinær diakonividenskab i mine øjne ikke et efterstræbelsesværdigt mål. Det spørgsmål er imidlertid ikke relevant i en dansk kontekst, hvor diakonividenskaben først at ved at flytte ind på universitetet. Her gælder det tværtimod om, efter at have fået søsat et tværfagligt studium, også at udvikle et interdisciplinært forskningssamarbejde, hvor de teologiske fag, særligt den praktiske og systematiske teologi, er naturlige medspillere.

\section{Afslutning}

Lad os til slut vende tilbage det ovenfor skitserede paradoks, at kirkerne i deres ekklesiologiske selvforståelse bliver mere og mere diakonale, alt imens diakonale organisationer i stigende grad får en min- 
dre eksplicit kristen og kirkelig profil og i højere grad reguleres og finansieres af sekulære verdslige instanser. Det første forhold peger i retning af nødvendigheden af at styrke diakonien som en selvstændig teologisk sub-disciplin, mens det sidste peger i retningen af en tværfaglig diakonividenskab, der respekterer praksisfeltets udstrakte selvstændighed i.f.t. kirken. Heldigvis er det ikke et spørgsmål om at vælge mellem de to, men tværtimod med Nordstokke at fastholde nødvendigheden af begge tilgange og at lade spændingen imellem dem være udgangspunkt for en gensidig inspiration og berigelse. En ren teologisk beskæftigelse med diakonien ville ikke kunne yde det store og komplekse diakonale praksisfelt retfærdighed og ville være irrelevant i forhold til en lang række af de problemstillinger, der i dag beskæftiger diakonale aktører. På samme måde ville en helt selvstændig og fra teologien løsrevet diakonividenskab være i fare for at smelte sammen socialvidenskaberne og dermed også at overtage de menneske-, samfunds- og tilværelsesforståelser, der på godt og ondt er præget af et sekulært-humanistisk og ofte ukritisk moderne og progressivistisk verdenssyn. Med teologien som fast integreret partner i diakonividenskaben fastholdes der et distinkt syn på diakonien som en praksis, der også altid i sidste ende har gudsriget som sin horisont (Moltmann 1984, 22). Derfor må diakonien - dersom den ønsker at fastholde sit navn på en meningsfuld måde - på forskellig vis udgå fra kirken og forstås som en del af Guds sendelse til verden. Dermed sikres det ligeledes, at diakonividenskabens perspektiv og referenceramme bliver videre end den vestlige senmoderne velfærdsstat og vestligt udviklingsarbejde i det globale syd: Diakoni, forstået som pro-social kristen praksis, er et centralt element i langt de fleste kristne kirkers selvforståelse og virkefelt - $\mathrm{i}$ hele verden. Dermed bliver den økumeniske teologi, missionsteologien og i stigende grad religionsteologien også relevante samtalepartnere for en globalt orienteret diakonividenskab. 